\title{
ПРЕДПОСЫЛКИ И ОСНОВАНИЯ СТАНОВЛЕНИЯ ПЕРСОНАЛИСТИЧЕСКОЙ АНТРОПОЛОГИИ СОВРЕМЕННОГО ЭКЗИСТЕНЦИАЛЬНОГО АНАЛИЗА: ОТ ИДЕИ К ПРАКТИКЕ
}

\author{
В.Б. ШУМСКИЙ ${ }^{a}$ Е.М. УКОЛОВА \\ ${ }^{a}$ Национальный исследовательский университет «Высшая школа экономики», 101000, Россия, \\ Москва, ул. Мясницкая, д. 20
}

\section{Background and Basis of Personalistic Anthropology of Modern Existential Analysis: From Idea to Practice}

\author{
V.B. Shumskiy ${ }^{\mathrm{a}}$, E.M. Ukolova ${ }^{\mathrm{a}}$
}

${ }^{a}$ HSE University, 20 Myasnitskaya Str., Moscow, 101000, Russian Federation

\begin{abstract}
Резюме
Современный экзистенциальный анализ как направление психологической науки и практики развивается благодаря диалогу с философией, академической психологией, теоретическими моделями и практическими методами различных школ психотерапии. Именно такой диалог в последнее десятилетие привел к существенному развитию представлений о духовном измерении человека, составляющих базис экзистенциально-аналитической антропологии - дифференциации феноменальных проявлений духовного измерения на Я и личность и соответствующей понятийной концептуализации. В настоящей статье впервые систематизированы развиваемые в последних работах А. Лэнгле представления о духовном Я как центре самосознания, принятий решений, волевой активности человека и духовной личности как центре ориентации в пространстве сущности бытия. Прослеживается преемственность линии развития идеи личности от философской антропологии М. Шелера и психологии поиска смысла В. Франкла к современному экзистенциальному анализу
\end{abstract}

\begin{abstract}
Modern existential analysis, as a school of psychological science and practice, is developing through dialogue with philosophy, academic psychology, theoretical models and practical methods of various approaches in psychotherapy. In the last decade this dialogue has led to a significant development of ideas about the spiritual dimension of a human being, which form the basis of existential-analytical anthropology - the differentiation of phenomenal manifestations of the spiritual dimension into the Self and the Person and the corresponding conceptualization. This article systematizes the ideas developed in the recent works of A. Längle regarding the spiritual Self as a center of self-consciousness, decision-making and volitional activity of an individual, and the spiritual Person as the center of orientation in the field of the essence of being. We trace the continuity of the development of the idea of the Person, starting from the philosophical anthropology of M. Scheler through V. Frankl's psychology of the search for meaning to the modern existential analysis
\end{abstract}


А. Лэнгле. Концепты «духовное Я» и «духовная личность» рассмотрены как феномены человеческого бытия и как теоретические конструкты. Подробно проанализировано теоретико-методологическое значение различения Я и личности для понимания проблемы аутентичности и генеза индивидуальных различий, преодоления абсолютизации психоноэтического антагонизма концепции В. Франкла, раскрытия важности внутреннего диалога в динамике самоотношения и самоосуществления. Обосновано понимание развития человека как становление его духовного Я и способности предоставлять личности пространство возможностей в человеческом бытии, а также понимание психического здоровья, психических расстройств и релевантный подход к разработке стратегии и методики психотерапии. Показаны философско-методологическая и культурно-историческая перспективы развития идеи личности в современном экзистенциальном анализе.

Ключевые слова: культурогенез идеи личности, персоналистическая антропология, экзистенциальная психология, экзистенциальный анализ, духовная личность, духовное Я, взаимодействие Я и личности, внутренний диалог, интегральная модель психотерапии.

Шумский Владимир Борисович - доцент, Центр фундаментальной и консультативной персонологии, департамент психологии, факультет социальных наук, Национальный исследовательский университет «Высшая школа экономики», кандидат психологических наук.

Сфера научных интересов: методология и история психологии, экзистенциальная философия и психология, психология личности, психология внутреннего диалога, психологическое консультирование, психотерапия.

Контакты: vshymsk@hse.ru

Уколова Елена Михайловна - старший преподаватель, Центр фундаментальной и консультативной персонологии, департамент психологии, факультет социальных наук, Национальный исследовательский университет «Высшая школа экономики», кандидат психологических наук. of A. Längle. The concepts of "spiritual Self" and "spiritual Person" are considered as the phenomena of human existence as well as theoretical constructs. The theoretical and methodological significance of the distinction between the Self and the Person for understanding the problem of authenticity and the genesis of individual differences, overcoming the absolutization of psychonoetic antagonism of V. Frankl's theory, revealing the importance of inner dialogue in the dynamics of relation to oneself and self-realization is analyzed in detail. We substantiated the understanding of human development as the establishment of his spiritual Self and the ability to provide the Person with a space of opportunities in human existence, as well as the understanding of mental health and mental disorders and the corresponding approach to development of a strategy and methods of psychotherapy. The philosophical-methodological and cultural-historical prospects of the development of the idea of the Person in modern existential analysis are shown.

Keywords: cultural genesis of the person, personalistic anthropology, existential psychology, existential analysis, spiritual person, spiritual self, interaction between self and the person, inner dialogue, integral model of psychotherapy.

Vladimir B. Shumskiy - Associate Professor, Department for Fundamental and Consulting Personology, School of Psychology, Faculty of Social Sciences, HSE University, $\mathrm{PhD}$ in Psychology.

Research Area: methodology and history of psychology, personality psychology, existential philosophy and psychology, psychology of inner dialogue, psychological counselling, psychotherapy.

E-mail: vshymsk@hse.ru

Elena M. Ukolova - Senior Lecturer, Department for Fundamental and Consulting Personology, School of Psychology, Faculty of Social Sciences, HSE University, PhD in Psychology.

Research Area: personality psychology, existential psychology and psychotherapy, 
Сфера научных интересов: психология личности, методология преподавания психологии, психология межличностных отношений, экзистенциальная психология и психотерапия, психология развития, психологическое консультирование, детская и подростковая психология и психотерапия.

Контакты: eukolova@hse.ru developmental psychology, relational psychology, child and adolescent psychology and psychotherapy, psychological counselling.

E-mail: eukolova@hse.ru

\section{Введение}

Альфрид Лэнгле, ученик и коллега Виктора Франкла, один из ведущих современных экзистенциальных психологов и психотерапевтов, работает в НИУ ВШЭ с 2005 г. В этом году он отмечает 70-летний юбилей.

А. Лэнгле внес существенный вклад в развитие теории и практики экзистенциальной психологии и психотерапии: достаточно хорошо известны концепция фундаментальных экзистенциальных мотиваций (Лэнгле, 2005, 2019, 2020a), теория эмоций (Лэнгле, 2006, 2007), базовый метод экзистенциальноаналитической психотерапии «персональный экзистенциальный анализ» (Лэнгле, 2009; Лэнгле и др., 2014). Благодаря его трудам экзистенциальная психотерапия из «дополнения» к другим школам психотерапии стала самостоятельным современным психотерапевтическим направлением, построенным на оригинальном теоретическом базисе экзистенциальной философии и психологии (Шумский, 2020).

Сотрудничая с профессором Лэнгле в департаменте психологии НИУ ВШЭ, авторы настоящей статьи могли наблюдать, как он в ходе диалогов с коллегами или отвечая на вопросы магистрантов дополняет и уточняет положения своей концепции. В последнее время в его статьях и лекциях оформляется существенная, с нашей точки зрения, понятийная дифференциация, касающаяся ядра теоретической концепции экзистенциального анализа - представлений о духовном (ноэтическом) измерении человека.

В статье раскрываются и систематизируются основные положения, характеризующие развитие антропологической модели современного экзистенциального анализа и рассматривается их методологическое значение для экзистенциальной психологии и психотерапии.

\section{Идея личности как краеугольный камень экзистенциального анализа: ретроспектива}

Антропологическая модель экзистенциального анализа базируется на одной из основных интуиций европейской культуры о сущности человека идее человека как существа, способного совершать свободный выбор, принимать самостоятельные решения. Начиная с поздней Античности и распространения христианства такое понимание человека было представлено в религиозно-философском концепте «личность» (Мосс, 2011; Розин, 2021). 
В начале XX в. немецкий философ М. Шелер преобразовал религиозную идею личности в философско-антропологическую категорию, раскрыл специфику личностного бытия по отношению к природному и социальному бытию человека. Именно представления М. Шелера о личности, на которых мы коротко остановимся, стали основанием логотерапии В. Франкла и современного экзистенциального анализа А. Лэнгле.

\section{Понимание личности в философской антропологии М. Шелера}

Сущностным признаком, отличающим человека от животного, М. Шелер полагает дух как внеприродный принцип, противостоящий сфере психовитального и телесного, которая роднит человека с животным миром. Центр духовного бытия человека - «деятельный центр, в котором дух является внутри конечных сфер бытия» - М. Шелер называет «личностью» (Шелер, 1988, с. 53). Реконструируя представления немецкого философа о личности, мы выделили следующие основные положения (Уколова, Шумский, 2016):

1. Человеческое существо представляет собой диалектическое единство жизни и духа. «Жизнь» связана с психофизическим организмом человека, «дух» - со сверхвитальным началом, не выводимым из жизни и не сводимым к ней. «Личность» выступает как «действующий агент» духовного бытия человека, который инициирует и осуществляет духовные акты.

2. Бытие личности характеризуется динамическим взаимодействием с психофизическим организмом человека: сублимацией «энергии жизни» в «духовную энергию», координацией и перенаправлением витальных импульсов на деятельность по воплощению ценностей. Но если человек оказывается во власти влечений и сиюминутных импульсов, он может утрачивать бытие личностью и вести существование, целиком пребывая во власти своих чувственных порывов.

3. Личность не субстанциональна и не пространственна; бытие личности не обладает временно́й непрерывностью. Как «деятельный агент», личность существует - или появляется и проявляется - в самоустановлении, самоосознании и самоосуществлении.

4. Личность проявляет себя в следующих духовных актах:

- мышлении в идеях;

- постижении сущностных форм устройства мира;

- восприятии и переживании ценностей;

- принятии решений;

- волевой активности, направляемой идеями и ценностями;

- переживании высших эмоциональных состояний, таких как любовь агапэ (agápē), доброта, прощение, сострадание, почитание, раскаяние, стыдливость и др.

5. Личность обладает «бытийной самостоятельностью», которая выражается в свободе, независимости от принуждения и давления со стороны как внешних обстоятельств, так и внутренних условий. Личность принципиально не обусловлена физическими, психическими или социологическими законами, но эти законы задают личности границы ее свободы. 
6. Личность обладает способностью к феноменологическому восприятию «сущностному видению» структуры мира и иерархии ценностей, предлагающей человеку основания для оценок, осуществления выбора и поступков.

7. Человек не может объективировать собственное бытие личностью, однако способен почувствовать себя личностью благодаря переживанию самого себя центром духовных актов. Также и другие люди как личности не могут быть объективированы. Возможно только соучаствовать с другой личностью в ее бытии посредством собственных переживаний и размышлений и понять другого человека как личность, идентифицируя себя с ним.

8. Личность, с одной стороны, в содержательном и ценностном аспектах неразрывно связана с окружающим миром, а с другой стороны, отделена от мира и противопоставлена миру - как внешнему, так и собственному психофизическому организму. Как личность, человек обладает способностью к духовному дистанцированию от самого себя и от мира и, как следствие, к объективации собственного психофизического бытия и окружающего мира.

9. Человек духовно «открыт миру» в его содержательной и ценностной сущности вследствие способности личности освобождаться от давления и принуждения со стороны психофизического бытия.

10. Ценности есть онтологические феномены, существующие объективно и независимо от человека и обладающие априорной иерархической структурой. Личность принадлежит к наивысшей ступени априорной иерархии ценностей.

11. Каждое человеческое сообщество и каждый отдельный человек имеют собственную, исторически изменчивую структуру восприятия и переживания ценностей, которая задает личности правила предпочтения ценностей и определяет мировоззрение человека. «Индивидуально-действенные ценности», являющиеся мотивами поступков конкретного человека как личности, распознаются им благодаря совести.

12. Актуализируя свое личностное начало, человек обретает свободу и ответственность формировать самого себя и свою жизнь посредством усилий собственного духа.

\section{Личность: от философско-антропологического к психологическому дискурсу}

В. Франкл писал: «Вспомним определение Макса Шелера, которое он дает личности: он называет ее исполнителем и центром духовных актов» (2000б, c. 228). Понимание личности, представленное в философской антропологии М. Шелера, он использовал в теории и практике логотерапии, показав его психологический потенциал и психотерапевтическую релевантность (Франкл, $2015,2020)$. Обозначим те аспекты концепции В. Франкла, которые развивают персоналистические идеи М. Шелера (Уколова, Шумский, 2016):

1. Промежуточной ступенью от философско-антропологического дискурса к психологическому - к описанию и пониманию индивидуального человеческого бытия - в концепции В. Франкла выступает экзистенциальная философия. 
В его работах осуществлен синтез персоналистической антропологии и экзистенциальной онтологии, тем самым идея духовной личности была привнесена в экзистенциальную психологию и психотерапию.

2. Тезис о стремлении личности к смыслу становится центральным.

3. Традиционная для европейской культуры «трехчленная» модель человека (тело - психика - дух) представлена в концепции В. Франкла в виде трех ортогональных измерений («димензиональная антропология и онтология»). В этой модели предложено оригинальное для психологических подходов разделение нематериальной человеческой реальности на психическую и духовную. В основе динамики психического измерения человека - стремление к удовольствию, в основе духовной динамики («ноодинамики») - стремление к смыслу'.

4. Предложено различение сознательного и бессознательного в духовном бытии человека: «Духовная личность в принципе может быть как сознательной, так и бессознательной; мы можем сказать, что духовная глубинная личность обязательно бессознательна... дух по своему происхождению есть дух бессознательный» (Франкл, 2000б, с. 232). Важной задачей сознательного духовного Я является осознание бессознательных духовных содержаний и воплощение их в поступках.

5. Идея личности как «действующего агента», как духовного начала человеческого бытия, направленного на воплощение смысла, является у В. Франкла базисом для построения теории и практики логотерапии. Философские положения о личности, сформулированные М. Шелером в самом общем виде, В. Франкл сделал практически применимыми к пониманию индивидуальной жизни и помощи конкретному человеку в его страдании.

Можно выделить следующие проблемные аспекты представлений В. Франкла, которые также представляют собой «точки роста» для становления идеи духовной личности в качестве психологической категории:

- религиозные представления о генезе личности (Франкл, 2000б; Frankl, 1951, 1997);

- абсолютизация «психоноэтического анатагонизма» как принципа взаимодействия телесно-психического и духовного начал человека;

- поставлена, но не получила развернутого решения проблема взаимодействия «сознательного духовного Я» и «бессознательной глубинной личности»;

- отсутствуют представления об индивидуальных различиях в способности проживать личностное начало и представления о процессе становления человека личностью в онтогенезе.

Дальнейший шаг в развитии психологических представлений о духовной личности осуществлен в экзистенциальном анализе А. Лэнгле.

\footnotetext{
${ }^{1}$ Категория «личность» в учении В. Франкла относится к духовному измерению человеческого бытия. В. Франкл последовательно стремился отграничиться от религиозных коннотаций в понимании духовности, подчеркивая, что «духовное измерение» в его концепции «является антропологическим, а не теологическим» (Франкл, 2000а, с. 229). В рамках настоящей статьи мы также будем использовать термин «личность», или «духовная личность», применительно к духовному измерению человеческого бытия.
} 


\section{Развитие идеи личности в экзистенциальном анализе А. Лэнгле}

Если в концепции В. Франкла идея личности находится скорее на заднем плане проблематики поиска смысла, то А. Лэнгле поставил категорию «личность» и основания для актуализации бытия человека личностью в центр теории и практики экзистенциального анализа: ВВ экзистенциальном анализе мы видим сущность человека в его бытии-личностью» (Längle, 2013, S. 49). B coответствии с этим «специфическая точка приложения сил в экзистенциальноаналитической работе состоит в том, чтобы сделать возможной реализацию сущности человека в рамках тех требований и той проблемы, которые существуют в его мире» (Лэнгле, 2020б, с. 24).

\section{Методологические посылки}

А. Лэнгле основывается на постулируемой М. Шелером способности духовной личности к феноменологическому восприятию, к постижению сущностной структуры мира и человеческого бытия.

Задача феноменологии в самом общем виде может быть сформулирована как экспликация непосредственного, метанарративного довербального опыта человека с целью выявления его инвариантных оснований. В свою очередь, результаты феноменологического познания описываются с использованием того или иного уровня обобщения, с выделением структуры, связей и закономерностей познаваемой реальности.

В первой трети XX в. такую задачу, как известно, поставил перед собой М. Хайдеггер, который на основе феноменологии создал «фундаментальную онтологию» человеческого бытия. Предлагая альтернативу традиционной «антично-христианской антропологии», он разработал для описания человеческой реальности особый язык и особую систему понятий-экзистенциалов (Хайдеггер, 2001, 2003). Однако язык экзистенциалов является философским, не предназначенным для решения задач конкретных наук, таких как психология и психотерапия. Кроме того, с нашей точки зрения, при использовании особого языка М. Хайдеггера для описания человеческой реальности происходит определенное рассогласование с предшествующей историкокультурной традицией понимания человека.

В отличие от этого в концепции А. Лэнгле обобщение результатов феноменологического познания бытия осуществляется с использованием слов, в которых человек понимает самого себя и свой повседневный субъективный опыт: согласие, справедливость, опора, пространство, защищенность, доверие, надежда и т.п. - одновременно с использованием существующего категориального аппарата психологии и психотерапии (Лэнгле, 2005, 2006, 2019, 2020а).

Можно сказать, что такой методологический подход соответствует сформулированной в начале XXI в. позиции метамодернизма, которая предлагает интеграцию модернизма и постмодерна - возврат к общим концепциям и универсальным истинам с одновременным признанием релятивизма, изменчивости и множественности человеческого существования (Vermeulen, van den Akker, 2010). 


\section{Конщептуальная дифференциация проявлений духовного измерения человека}

Развитие научного знания происходит в значительной степени благодаря дифференциации предметной области конкретной науки. Это позволяет выделять в познаваемой реальности существенные компоненты, более детально изучать как сами компоненты, так и их взаимодействие. Различение глубинной бессознательной духовной личности и сознательного духовного Я, как упоминалось выше, было намечено В. Франклом. Однако основатель логотерапии только указал на возможность подобной дифференциации.

В работах А. Лэнгле до 2014 г. категория «личность» (Person) относилась ко всему духовному измерению человека: «Личность - центральное понятие экзистенциального анализа, используемое для описания духовного измерения человека и его способности к экзистенции» (Längle, 2008, S. 35). В книгах и статьях присутствовало разделение на духовную личность и духовное Я человека, однако это различение не было ясно концептуализировано. В статье 2014 г. «Die Aktualisierung der Person. Existenzanalytische Beiträge zur Personierung der Existenz» (Längle, 2014a) проведено последовательное различение: ряд феноменов духовного измерения человека концептуализируется как «личность», тогда как другие феномены духовного измерения концептуализируются как проявление человеческого Я.

Можно сказать, что в самом общем виде задачей духовного Я человека является принятие решений и осуществление этих решений в направляемых волей поступках. Назначение духовной личности как сущности человека состоит в том, чтобы устанавливать существенные отношения со всем, с чем человек соотнесен, и предлагать человеку такие способы поведения, отношения к самому себе и к окружающему миру, в которых он в наибольшей степени соответствовал сущности бытия и мог быть самим собой.

Разграничение духовной личности и духовного Я имеет, с нашей точки зрения, важное значение для развития теории и разработки методов консультирования и психотерапии в современном экзистенциальном анализе. Покажем, как представлено в концепции А. Лэнгле описание духовной личности, духовного Я и их взаимодействия.

\section{Духовная личность как феномен человеческого бытия}

Работы А. Лэнгле позволяют выделить ряд основных аспектов проявления духовной личности во внутреннем мире человека (Лэнгле, 2005; Längle, 2013, 2014a, 2014b):

1. Постоянно присутствующее в человеке чувство согласованности/несогласованности, соответствия/несоответствия, согласия/несогласия, гармонии/дисгармонии с тем, где он находится и чем занят в данный момент. Это фоновое оценочное чувство, всегда сопровождающее человека, субъективно может переживаться как: «Это мне походит, соответствует; я с этим согласен». 
2. Ощущение резонанса, которое появляется у человека рядом с тем, что в особенной степени переживается как соответствующее ему: «Это мое!»; «Вот здесь я - на своем месте!» Появляется переживание, что я на своем месте в этом городе, рядом с этим человеком или рядом с этими людьми в этой профессиональной деятельности. Сюда же можно отнести персональную любовь как резонанс между сущностью Я и сущностью Ты, как восприятие другого человека в его глубине и потенциалах развития.

3. Некий «внутренний голос», или внутренний импульс, стремящийся обратить внимание человека на существенное, которое он пока не замечает: «Вот это - на самом деле твое», «Тебе - сюда!», «Посмотри, как красив этот заход солнца, как хороша эта музыка, как прекрасен этот мир!»

4. Творческие импульсы, а также озарения и инсайты, которые приходят к человеку относительно его самого и его собственного поведения или понимания того, как устроен окружающий мир.

5. Голос совести, который советует, предостерегает, одобряет в ситуации выбора и принятия человеком решений. Голос совести также предъявляет человеку результаты оценивания на основе глубинного интуитивного чутья: являются ли правильными или неправильными действия, планируемые и совершенные самим человеком или другими людьми.

6. Речь собеседника во внутреннем диалоге человека с самим собой.

Со стороны внешнего наблюдателя проявления личностного начала в другом человеке можно увидеть и почувствовать:

1. В особенном блеске глаз, отражающем полную включенность в происходящее; в звучании голоса, идущего словно из самой глубины человека; в плавности и соразмерности движений, в ощущении спокойствия, внутренней прочности, уверенности, целостности, которое словно бы излучается таким человеком.

2. В диалогической Встрече, когда с откровенностью, взаимопониманием и эмпатией происходит глубокое внутреннее общение с собеседником и словно бы открывается возможность прикоснуться к самой сокровенной его сердцевине.

\section{Духовная личность как теоретический конструкт}

А. Лэнгле отмечает, что опирается на представления М. Шелера о личности (Лэнгле, 2009), и часто ссылается на работы М. Шелера (Лэнгле, 2005, 2019, 2020a; Längle, 2014a, 2014b). Вместе с тем мы можем сказать, что концепция духовной личности в современном экзистенциальном анализе является существенным развитием понимания личности, представленного в трудах немецкого философа. Выделим основные, на наш взгляд, положения А. Лэнгле о духовной личности:

1. Личность есть сущность человека, его подлинное, «аутентичное Я»; экзистенция - это осуществление бытия личностью.

2. Личность не имеет субстанции; личность - это уникальное, автономное, свободное духовное бытие.

3. Личность существует в постоянной соотнесенности с внутренним и внешним миром человека, однако в этой соотнесенности она сохраняет свою 
самостоятельность. Иными словами, соотнесенность личности характеризуется «неслиянностью и нераздельностью»: одновременной отграниченностью от Иного и связанностью с Иным.

4. Личность существует только в настоящем, в каждый момент времени соотносясь с вновь изменяющимися реалиями внутреннего мира человека и внешнего мира, в котором он находится.

5. Соотнесение духовной личности с внешним и внутренним миром характеризуется диалогом; диалог понимается как способ бытия личности.

6. В диалогическом взаимодействии личности можно выделить три этапа: восприятие, интеграция, занятие позиции. Благодаря способности к феноменологическому видению личность воспринимает и распознает существенное и устанавливает сущностные отношения с тем, где человек сейчас находится, с чем он соотнесен, и тем, что происходит в его внутреннем мире. Далее личность интегрирует установленные сущностные взаимосвязи и соотносит их с собой. За интеграцией следует занятие личностью позиции по отношению к тому, чем человек занимается и где он находится в настоящий момент.

7. Личность стремится к присутствию в мире - стремится к тому, чтобы ее позиция была «услышанной»: во внутренней беседе с духовным Я или во внешнем мире, во Встрече с другим человеком как личностью.

8. Во внутреннем мире личность обращается к Я человека, и в этом обращении личность является «говорящей» - посредством чувств или внутренней речи.

9. Устанавливая сущностные отношения с внутренним и внешним миром и занимая позицию, личность предлагает Я человека ориентацию, следуя которой он может быть самим собой и одновременно соответствовать сущности бытия в контексте конкретной жизненной ситуации.

10. Бытие личностью дано человеку как врожденная предрасположенность. Личность как постоянное ситуативное занятие позиции, выражающееся в адресуемом Я чувстве соответствия/несоответствия, присутствует в человеке всегда. Таким образом, бытие-личностью есть потенциальная возможность; однако будет ли эта возможность реализована, зависит от Я человека.

Можно увидеть, что А. Лэнгле внес в концепцию духовной личности два принципиальных изменения по сравнению с пониманием личности у М. Шелера - В. Франкла:

1. Положение о диалоге как о сущностной характеристике личности.

2. Личность в концепции А. Лэнгле не рассматривается в качестве «деятельного центра», как это было у М. Шелера, но в качестве «центра ориентации» - ориентирования в пространстве сути бытия. В качестве деятельного начала человеческого бытия, или активного агента духовного измерения, согласно А. Лэнгле, выступает Я человека.

\section{Духовное Я как феномен человеческого бытия}

Субъективное переживание собственного Я, или Я как феномен, является многогранным: человек переживает себя как Я благодаря своему телу, благодаря своим чувствам, благодаря своей способности мыслить и познавать мир, 
благодаря своим действиям, а также благодаря способности распознавать то, что является «правильным» (Лэнгле, 2005; Längle, 2014a). Переживание своего Я содержит как идентификацию, так и разотождествление: «Я есть мое тело» и «У меня есть тело»; «Я есть мои чувства» и «У меня есть чувства». Исходя из того, как переживается человеком собственное Я, можно сказать, что Я представляет собой телесную, психическую и духовную величину, одновременно пассивно-воспринимающую и активно-деятельностную.

В субъективном опыте переживания Я распознаваем существенный аспект, который далее мы будем обозначать как «духовное Я». Переживание этого духовного аспекта собственного Я, или базовое онтологическое переживание «я-есть», или «экзистенциальное пробуждение», является отправной точкой для теоретических построений экзистенциальной философии и психологии (Мэй, Ялом, 2008). Это переживание своего Я в его радикальной отделенности от других людей, окружающего мира и одновременно разотождествленности и дистанцированности от собственного тела, мыслей, чувств, жизненной истории, т.е. переживание некоторого неуничтожимого остатка, который человек ощущает в себе.

Переживание «я-есть», пришедшее к человеку впервые, может вызвать у него состояние, близкое к мировоззренческому шоку, и породить множество вопросов. Основатель экзистенциальной философии С. Кьеркегор в первой половине XIX в. формулировал их так: «Где я? Что такое мир? Что означает самое это слово? Кто обманом вовлек меня сюда и бросил на произвол судьбы? Кто я? Как я пришел в мир? Почему меня не спросили раньше, не познакомили со здешними нравами и обычаями, а прямо втиснули в шеренгу, словно рекрута, завербованного поставщиком душ?» (Кьеркегор, 1997, с. 89). Эти вопрошания удивительно перекликаются с тем, как во второй половине XX в. формулирует основные проблемы экзистенциальной психологии Дж. Бьюдженталь: «Кто я или что я? В своем последнем основании? Помимо званий, ролей, степеней и всех этих этикеток, наклеенных на меня? Помимо занятий и отношений, даже имени и личной истории? Кто я? Что я?» (Бьюдженталь, 1998, с. 33).

Именно благодаря переживанию духовного Я как своего «неуничтожимого остатка» человек может осознать себя «решающим бытием», «активным агентом», «действующим Я», т.е. самостоятельным, автономным существом, обладающим собственным топосом в иерархии мироздания.

\section{Теоретическая рефлексия духовного Я человека}

Согласно позднему варианту концепции А. Лэнгле, благодаря духовному Я человек способен осознанно формировать свою жизнь, управлять своей жизнью. Соотносясь с внешним и внутренним миром человека, Я как духовная инстанция согласовывает внутреннюю и внешнюю реальности: координирует способности человека с условиями и возможностями, предоставляемыми внешней ситуацией, выбирает, принимает решения и исполняет их. Для принятия и осуществления решений в распоряжении Я находятся психические 
функции: ощущение, восприятие, память, мышление, речь. Духовному Я как центру рефлексии и самосознания человека также необходимо хорошее соотнесение с телом и чувствами.

Во внешнем мире Я соотнесено с содержаниями четырех фундаментальных экзистенциальных мотиваций и должно быть способно осуществлять деятельность по реализации этих мотиваций: выдерживать и принимать условия и обстоятельства жизни, в которых находится человек, эмоционально открываться ценностям, воспринимать Иное с уважением, занимать позицию, видеть взаимосвязи и контексты, в которые включен человек, смотреть в будущее, действовать с самоотдачей. Кроме того, Я необходима укорененность в базовых структурах экзистенциальных мотиваций: в фундаментальном доверии, ценности жизни, самоценности и чувствовании смысла (Längle, 2014b).

А. Лэнгле выделяет три вида внутренней деятельности человека в обхождении с самим собой, которые являются основой формирования внутреннего диалога и переживания силы духовного Я: восприятие самого себя, принятие всерьез своих чувств и вынесение суждения о себе. Предпосылками для осуществления этой внутренней деятельности является опыт, который человек получает в интерперсональном общении и в отношениях с другими людьми опыт заинтересованного внимания и справедливого отношения к себе, а также признание собственной ценности со стороны других (Ibid.). Таким образом, A. Лэнгле подчеркивает, что Я человека изначально формируется в общении с другими людьми - в соответствии с тем, как это было сформулировано в персоналистической философии и философии диалога (Бубер, 1995; Мунье, 1999).

Я человека приобретает наибольшую силу, когда соотносится с духовной личностью. Если человек действует в согласии со своей совестью, то в таком поступке собственное Я переживается как наиболее реальное, сильное и прочное (Лэнгле, 2019).

\section{Взаимоотношения Я и личности}

В качестве следующего шага выделим основные методологические следствия дифференциации проявлений духовного измерения человека на Я (самосознание, принятие и осуществление решений) и личность (ориентация в пространстве сущности бытия).

\section{Проблема принятия собственных решений}

Что является основанием для решений, которые принимает Я человека? Я свободно в своем выборе. Принимая решения, Я как духовная инстанция может опираться на прошлый опыт, на привычные паттерны поведения, усвоенные в процессе воспитания и социального научения, на мораль социальной группы, к которой человек чувствует принадлежность, на различные мировоззренческие концепции. Человек может временно утрачивать свое принимающее решения Я под натиском сиюминутных искушений, инстинктивных импульсов и овладевающих им эмоций. 
Если человек действует автоматически, реагирует спонтанно, оказываясь отданным во власть возникающих в нем эмоций, тогда у него может появиться ощущение, что это действует словно бы не он сам, а нечто заставляет его вести себя тем или иным образом. С другой стороны, человек может принимать сознательное решение, не согласуясь с духовной личностью и даже не предполагая о ее существовании, и при этом у него может появиться ощущение, что решение принял он сам, его Я. Но действительно ли «он сам» принимал такое решение? 3. Фрейд утверждал, что если человеку кажется, что решение принимает его Я, то это только иллюзия - решение за него принимает бессознательное, в котором властвуют сексуальный и агрессивный инстинкты (Фрейд, 2015). Постмодернистское мировоззрение, провозгласившее «смерть субъекта», также растворило Я, обосновывая тотальную детерминированность человека лингвистическими структурами и дискурсивными социальными практиками (Лиотар, 1998).

Координирующее внешнюю и внутреннюю реальности человека и принимающее решения Я не может быть основанием для самого себя. Это Я, данное как несомненное и достоверное переживание, есть некая необъективируемая «пустота в густоте бытия», «ничто» (Сартр, 2002). И поэтому Я нуждается в опоре на что-то внешнее, во внешних по отношению к себе основаниях для принятия решений.

Осознание собственного Я, своей уникальности и автономности может обернуться переживанием радикального одиночества и страха. В этой связи И. Ялом подчеркивает: «Чистое ощущение бытия, “я-есть”, чувство собственного бытия как истока вещей слишком пугает, погружая в изоляцию, поэтому человек отрицает самотворение» (Ялом, 2004, с. 424). От страха бытия собой человек бежит в социум, растворяя свое Я в социальных ролях и сценариях.

Противоположная возможность состоит в том, что человеку необходимо в самом себе искать прочные основания для решений и действий. Духовная личность ориентирует человека по направлению к «са́мой своей способности быть», если воспользоваться формулировкой М. Хайдеггера (2003, с. 316). Человек становится сущностным, когда его Я предоставляет духовной личности пространство, чтобы личность, благодаря Я, смогла проявиться в поведении человека и в его поступках. Если Я действует, не соотносясь с духовной личностью, тогда человек живет, не следуя тому, о чем говорит ему его сущность, и поэтому не является целостным.

Когда человек проживает свое бытие личностью, он «является самим собой», «является собой подлинным, собой-настоящим», если описывать его переживания, или является аутентичным, если обозначать это переживание в психологическом дискурсе. Такой человек чувствует внутреннее спокойствие, свободу от мук противоположных устремлений, переживает себя целостным и является психически здоровым. В соответствии с этим цель экзистенциального анализа, как считает А. Лэнгле, состоит в том, чтобы помогать людям жить свободной и аутентичной жизнью (Längle, 2019b, p. 319). 


\section{Преодоление абсолютизачии психоноэтического антагонизма учения В. Франкла}

В своей «димензиональной антропологии» В. Франкл подчеркивал фундаментальное различие свободного, недетерминированного духовного измерения и детерминированной плоскости психофизического, определяя его как «психоноэтический антагонизм». Этот антагонизм «дает человеку возможность утвердить себя в своей человечности наперекор телесно-психическим состояниям» (Франкл, 2000а, с. 111), вступая «в противостояние телесным и психическим феноменам» (Там же, с. 11). В. Франкл утверждал, что человек «может реализовать себя лишь в той мере, в какой он забывает про себя, не обращает на себя внимания» (Там же, с. 30 ). Таким образом, в логотерапии имплицитно полагалось, что телесное и психическое измерения человеческого бытия представляют проблему для бытия человека духовной личностью и тем самым ограничивают человека в его возможностях находить и осуществлять смысл.

В отличие от этого в концепции А. Лэнгле утверждается, что свободная духовная личность, которую невозможно объять и зафиксировать, благодаря психическим способностям, находящимся в распоряжении духовного Я, взаимодействует со структурами психики и тела и тем самым проявляется в теле и психике человека. Установкой Я по отношению к собственной духовной личности является признание того, что сама эта личность может прийти в мир и воплотиться только благодаря Я. Иначе говоря, Я признает ответственность за актуализацию своей личности, за то, чтобы проживать собственное личностное начало. На основе этой установки и трем видам внутренней деятельности духовного Я как центра самосознания человека - заинтересованное внимание по отношению к себе, принятие себя всерьез и вынесение суждения о себе - духовная личность проявляется и в телесном, и в психическом, а не только выражает себя через телесное и психическое, как это представлено в учении В. Франкла. Тем самым обосновывается необходимость синергии духовного, телесного и психического в человеческом бытии (Längle, 2014b).

\section{Внутренний диалог как основа взаимодействия Я и личности: от односторонности к равноправному партнерству}

Представление о необходимости повиновения голосу совести как голосу Бога является традиционным для христианской культуры. Этот же посыл содержится и в учении В. Франкла (Франкл, 2000б). Речь идет об одностороннем взаимодействии Я и личности: задача Я состоит в том, чтобы быть внимательным в постоянной готовности расслышать и исполнить то, что «скажет» личность.

В отличие от этого в концепции А. Лэнгле обосновывается равноправие статусов духовного Я и духовной личности в человеческом бытии. Я и личность смотрят на мир с разных позиций: личность видит вещи с точки зрения их внутренней сущности, Я - с точки зрения практического использования; 
личность соотносится с тем, что является «принципиально правильным», Я с тем, что является «практически осуществимым». Эти перспективы в бытии человека должны быть согласованы, поэтому Я и личность изначально и неизбежно находятся в состоянии постоянного внутреннего диалога. Духовное Я и духовная личность обладают взаимодополняющими характеристиками: рациональное мышление и рефлексивность Я предлагают иной взгляд, чем интуитивное видение личности; изменение контекста и получение дополнительной информации о какой-либо ситуации или человеке, которое может предпринять сознательное Я, помогает избежать ошибок совести - все это делает восприятие себя и мира многограннее, объемнее. Личность говорит с Я - и в этой нескончаемой внутренней беседе двух визави человек одновременно и Я, и личность, которые обсуждают и проясняют, как поступить, как жить дальше. Личность и Я, таким образом, являются сомыслителями, сотрудниками, сотворцами в формировании человеком своей жизни. Диалог сознательного Я с духовной личностью представляет собой источник и основание самодетерминации, благодаря этому диалогу человек становится обоснованным и укорененным в самом себе и тем самым истинным субъектом жизни как причиной самого себя.

C нашей точки зрения, представления о равноправном диалогическом общении Я и личности не оставляют места для религиозных коннотаций в понимании духовной личности. В диалогическом подходе к духовному измерению человека проявления духовной личности утрачивают свой мистический, метафизический диктаторский характер. При этом «этически правильное» становится переживанием человека, которое не навязывается ему извне ни из социума, ни из потусторонности трансцендентности, - а появляется и созревает в процессе разговора с самим собой при принятии конкретного решения.

\section{Развитие Я и его способности предоставлять личностному пространство в человеческом бытии}

Вслед за персоналистической философской традицией А. Лэнгле полагает, что бытие личностью дано человеку как врожденная предрасположенность (Längle, 2014b). В то же время способность проживать бытие личностью приходит к человеку благодаря развитию Я и осознанию ответственности за актуализацию собственной личности. А. Лэнгле подчеркивает, что развитие духовного Я не ограничивается каким-либо возрастным периодом или этапом жизни, в противном случае были бы невозможны те изменения, которые происходят с человеком благодаря психотерапии (Лэнгле и др., 2014, с. 167). Чем более зрелым и структурированным является Я человека, тем более проявляется его способность обнаружить и расслышать голос личности, соотнестись с ним, вступить с ним в диалог и проживать личностное начало в конкретике своей жизни.

Мы можем отметить, что в контексте психологии развития представления А. Лэнгле содержат два важных момента: 
- развитие человека не ограничивается ранними возрастами - детством и юношеством; развитие человека в зрелом возрасте понимается и конкретизируется как становление способности Я проживать личностное начало;

- несмотря на то что развитие Я инициируется интерперсональным общением, решающая роль в развитии собственного Я и актуализации личности с определенного возраста принадлежит внутренней деятельности самого человека и характеризует его персональную зрелость.

Из перспективы духовного измерения человека индивидуальные различия можно соотнести с различиями в степени развития духовного Я, его способности вступать в соотнесение с личностью и создавать пространство для проявления личности в человеческом бытии. Отличия в том, насколько у Я сформированы способности к реализации той или иной фундаментальной экзистенциальной мотивации, становятся индивидуальным профилем, который характеризует специфические особенности во взаимоотношении Я и личности у конкретного человека. Эти особенности, исходя из экзистенциальноаналитической перспективы, и являются основой для описания и систематизации индивидуальных различий.

\section{Экзистенциальный анализ как интегральная модель психотерапии}

В основе психических нарушений с точки зрения экзистенциального анализа лежит отсутствие или ограниченность духовной способности Я актуализировать бытие личностью. Это может быть вызвано двумя основными факторами:

- дефицитами в реализации фундаментальных экзистенциальный мотиваций, что связано с недостаточностью «силы Я»;

- заблокированностью внутреннего диалога Я и личности (Лэнгле, 2020а).

Соответственно, для укрепления Я в структурах бытия необходима проработка дефицитов в темах отдельных фундаментальных экзистенциальных мотиваций. В экзистенциальном анализе А. Лэнгле разработаны специфические методы помощи пациентам, испытывающим конкретные проблемы или страдающим от определенных психических расстройств. Основной целью этих методов является укрепление «силы Я» (Längle, 2013).

Можно сказать, что каждое направление психотерапии центрируется на развитии того или иного аспекта сознательного духовного Я человека: психоанализ - на способности Я интегрировать психодинамические либидинозные и агрессивные импульсы, когнитивно-поведенческая терапия - на способности Я к научению, психодрама - на способности Я к эмоциональной открытости и экспрессивности и т.д. В то же время в экзистенциально-аналитическом понимании Я, с точки зрения концепции фундаментальных экзистенциальных мотиваций и процесса взаимодействия Я и Личности, представлены все аспекты способностей Я.

В контексте различения духовного Я и духовной личности разработанный А. Лэнгле психотерапевтический метод «Персональный экзистенциальный анализ» (ПЭА) можно рассматривать как последовательную многоаспектную 
процедуру реструктуризации диалогического общения Я и Личности (Längle, 2014b). В процессе ПЭА происходит поэтапная интеграция динамических сил телесной, психической и духовной природы, присутствующих в человеке. В сердцевине метода - нахождение согласованной с духовной личностью собственной позиции человека по отношению к конкретной жизненной ситуации. В переживании согласия с духовной личностью сознательное Я находит базис, на котором принимается аутентичное решение, реализуемое в ответственном поступке.

Если рассматривать ПЭА и происходящий в его рамках процесс согласования Я и личности с точки зрения содержаний и тем, лежащих в фокусе внимания основных направлений современной психотерапии, то можно утверждать, что в этом методе сочетаются:

- открытость по отношению к собственным чувствам, их осознание и принятие;

- понимание причин возникновения чувств и поведенческих реакций;

- интеграция чувств и реакций в актуальный и биографический контексты;

- прояснение и коррекция когнитивных и ценностных установок;

- обращение к глубинному чувствованию того, какое поведение является аутентичным в контексте данной жизненной ситуации;

- принятие решений и планирование деятельности по их осуществлению;

- тренировка новых способов поведения в проблемных ситуациях.

В ПЭА проводится комплексная и системная работа с темами и проблемными областями, характерными для психодинамических, когнитивно-поведенческих и экзистенциально-гуманистических подходов в психотерапии. Мы можем сказать, что выросший из экзистенциального анализа и логотерапии В. Франкла экзистенциальный анализ А. Лэнгле представляет собой, по сути, интегральную модель психотерапии.

\section{Заключение}

Развитие теории и практики современного экзистенциального анализа происходит благодаря многоплановому и разностороннему диалогу - с историей культуры и современным социокультурным контекстом, с академической психологией, с различными школами и направлениями психотерапии. В практике консультирования и психотерапии происходит диалог с пациентами, в образовательном процессе - диалог со студентами и коллегами. Без диалогического обмена, без постоянного переосмысления и проблематизации собственных концептов и принципов экзистенциальный анализ воспроизводил бы одно и то же знание, которое замыкалось само на себя в отрыве от современного развития методологии, теории и практики психологии и психотерапии.

В течение последнего десятилетия такой диалог привел к развитию представлений о духовной личности, лежащих в основе экзистенциально-аналитической антропологии - дифференциации феноменальных проявлений духовного измерения человека на Я и «личность» и соответствующей понятийной концептуализации. Благодаря этому, на первый взгляд, небольшому приращению 
теории стала возможна более точная и глубокая рефлексия исходных оснований, теоретических представлений, а также целей и методов работы в практике экзистенциального анализа. Стали яснее видны содержательная близость и конкретные точки пересечения с другими школами экзистенциальной психологии и психотерапии. Мы можем надеяться, что уточнение исходных теоретических оснований экзистенциального анализа станет надежной основой для дальнейшего развития его теории и методов.

Если посмотреть из философско-методологической перспективы, то можно попытаться увидеть значение, которое имеет совершенствование антропологической модели современного экзистенциального анализа для развития идеи личности, лежащей в основе европейской культуры. Начиная с Античности центральным в идее личности было понимание человека как существа, способного принимать самостоятельные решения, существа сознательного, автономного, независимого, свободного, ответственного. В Античности категория «личность» имела также этический аспект, а значение метафизической сущности человека было добавлено к категории «личность» в Христианстве (Мосс, 2011).

Мы можем сказать, что в предложенном А. Лэнгле концептуальном различении феноменов духовного измерения человека на Я и личность были методически выделены отдельные аспекты идеи личности: духовное Я сознательность, автономность, свобода, ответственность, социальная мораль; духовная личность - автономность, независимость, свобода и этика, соотнесенная с сущностью бытия. Одновременно с этим обосновывается необходимость постоянного внутреннего диалогического взаимодействия Я и личности. В целостном, психически здоровом человеке благодаря взаимодействию Я и личности все аспекты исходной «идеи личности» согласуются, приходят в равновесие, что, в конечном счете, позволяет человеку жить аутентично с внутренним согласием.

Культурно-историческое значение развития идеи личности, представленное А. Лэнгле, с нашей точки зрения, состоит в том, что он освободил идею личности от религиозных и метафизических коннотаций и предложил то, что может быть обозначено как «постхристианская антропология», отвечающая современным социокультурным реалиям и вызовам времени. При разработке оригинальной концепции экзистенциального анализа им был проделан путь от философско-антропологических оснований идеи личности к описанию духовной личности как психологической категории, раскрытой через систему понятий, операционализированных в методах консультирования и психотерапии.

\section{Литература}

Бубер, М. (1995). Два образа веры. М.: Республика.

Бьюдженталь, Д. (1998). Наука быть живым: диалоги между терапевтом и пациентами в гуманистической терапии. М.: Класс.

Кьеркегор, С. (1997). Повторение. Опыт экспериментальной психологии. М.: Лабиринт. 
Лиотар, Ж. Ф. (1998). Состояние постмодерна. СПб.: Алетейя.

Лэнгле, А. (2005). Person. Экзистенииально-аналитическая теория личности. М.: Генезис.

Лэнгле, А. (2006). Что движет человеком? Экзистенииально-аналитическая теория эмоций. М.: Генезис.

Лэнгле, А. (ред.). (2007). Эмоции и экзистениия. Харьков: Гуманитарный центр.

Лэнгле, А. (2009). Персональный экзистенциальный анализ. В кн. Е. Б. Старовойтенко, В. Д. Шадриков (ред.), Психология индивидуальности: новые модели и конщепщи (с. 356-382) М.: МПСИ.

Лэнгле, А. (2019). Воплощенная экзистенция. Развитие, применение и концепты экзистенциального анализа. Харьков: Гуманитарный центр.

Лэнгле, А. (2020а). Экзистенциальный анализ. М.: Когито-Центр.

Лэнгле, А. (2020б). Диалогика и Dasein. Как способствовать развитию психотерапевтического процесса в коммуникации и повседневной жизни. Экзистенциальный анализ, 12, 13-36.

Лэнгле, А., Уколова, Е. М., Шумский, В. Б. (2014). Современный экзистенциальный анализ: история, теория, практика, исследования. М.: Логос, 2014.

Мосс, М. (2011). Общества. Обмен. Личность. Труды по социальной антропологии. М.: КДУ.

Мунье, Э. (1999). Манифест персонализма. М.: Республика.

Мэй, Р., Ялом, И. (2008). Экзистенциальная психотерапия. Журнал практической психологии и психоанализа, 4, 101-144.

Розин, В. М. (2021). Личность и ее изучение. М.: URSS.

Сартр, Ж.-П. (2002). Бытие и ничто. Опыт феноменологической онтологии. М.: Республика.

Уколова, Е. М., Шумский, В. Б. (2016). Идея личности в экзистенциальном анализе Виктора Франкла. М.: Логос.

Франкл, В. (2000а). Воля к смыслу. М.: ЭКСМО.

Франкл, В. (2000б). Основы логотерапии. Психотерапия и религия. СПб.: Речь.

Франкл, В. (2015). Десять тезисов о личности. Экзистенциальная традищия: философия, психология, психотерапия, 1(26), 265-273.

Франкл, В. (2020). Логотерапия и экзистенциальньй анализ: статьи илекиии. М.: Альпина нон-фикшн. Фрейд, 3. (2015). «Я» $и$ «но». СПб.: Азбука.

Хайдеггер, М. (2001). Основные проблемы феноменологии. СПб.: Высшая религиозно-философская школа.

Хайдеггер, М. (2003). Бытие и время. Харьков: Фолио.

Шелер, М. (1988). Положение человека в космосе. В кн. П. С. Гуревич (ред.), Проблема человека в западной философии. Сборник статей (с. 31-95). М.: Прогресс.

Шумский, В. Б. (2020). Экзистенциальная психология и психотерапия. М.: Юрайт.

Ялом, И. (2004). Экзистенциальная психотерапия. М.: Класс.

Ссылки на зарубежные источники см. в разделе References.

\section{References}

Buber, M. (1995). Dva obraza very [Two types of faith]. Moscow: Respublika. (Original work published 1950) Bugental, J. (1998). Nauka byt' zhivym: dialogi mezhdu terapevtom i patsientami v gumanisticheskoi terapii [The search for existential identity: Patient-therapist dialogues in humanistic psychotherapy]. Moscow: Klass. (Original work published 1976) 
Frankl, V. E. (1951). Logos und Existenz. Drei Vortrage [Logos and existence. Three lectures]. Vienna: Amandus-Verlag.

Frankl, V. E. (1997). Man's search for ultimate meaning. New York: Perseus Book Publishing.

Frankl, V. E. (2000a). Volya k smyslu [The will to meaning]. Moscow: EKSMO. (Original work published 1969)

Frankl, V. E. (2000b). Osnovy logoterapii. Psikhoterapiya i religiya [Fundamentals of logotherapy. Psychotherapy and religion]. Saint Petersburg: Rech'. (Original work published 1948)

Frankl, V. E. (2015). Desyat' tezisov o lichnosti [Ten theses on the human person]. Ekzistentsial'naya Traditsiya: Filosofiya, Psikhologiya, Psikhoterapiya, 1(26), 265-273.

Frankl, V. E. (2020). Logoterapiya i ekzistencial'nyj analiz: stat’i i lektsii [Logotherapy and existential analysis: Articles and lectures]. Moscow: Alpina Non-fiction. (Original work published 1998)

Freud, S. (2015). "Ya" $i$ "Ono" [The Ego and the Id]. Saint Petersburg: Azbuka. (Original work published 1923)

Heidegger, M. (2001). Osnoznye problemy fenomenologii [The basic problems of phenomenology]. Saint Petersburg: Vysshaya religiozno-filosofskaya shkola. (Original work published 1927)

Heidegger, M. (2003). Bytie i vremya [Being and time]. Kharkiv, Ukraine: Folio. (Original work published 1927)

Kierkegaard, S. (1997). Povtorenie. Opyt eksperimental'noj psihologii [Repetition. A venture in experimental psychology]. Moscow: Labirint. (Original work published 1843)

Längle, A. (2005). Person: Ekzistentsial'no-analiticheskaya teoriya lichnosti [The Person: Existentialanalytical theory of personality]. Moscow: Genezis.

Längle, A. (2006). Chto dvizhet chelovekom? Ekzistentsial'no-analiticheskaya teoriya emotsii [What moves a human being? Existential-analytical theory of emotions]. Moscow: Genezis.

Längle, A. (Ed.). (2007). Emotsii i ekzistentsiya [Emotions and existence]. Kharkiv, Ukraine: Gumanitarnyi tsentr. (Original work published 2003)

Längle, A. (Ed.). (2008). Lexikon der Existenzanalyse und Logotherapie [Dictionary of existential analysis and logotherapy]. Vienna: GLE-Verlag.

Längle, A. (2009). Personal'nyi ekzistentsial'nyi analiz [Personal existential analysis]. In E. B. Starovoytenko \& V. D. Shadrikov (Eds.), Psikhologiya individual'nosti: novye modeli $i$ kontseptsii [Psychology of individuality: New models and concepts] (pp. 356-382). Moscow: MPSI.

Längle, A. (2013). To sense what is right? On authenticity and conscience. Existenzanalyse, 30(2), 4658. (in Deutsch)

Längle, A. (2014a). The actualization of the person. Existential analytical contributions to the personization of existence. Existenzanalyse, 31(2), 16-26. (in Deutsch)

Längle, A. (2014b). Lernskriptum zur Existenzanalyse: Dritte Grundmotivation [Educational materials on existential analysis: The third existential fundamental motivation]. Vienna: GLE-Werlag.

Längle, A. (2019a). Voploshchennaya ekzistentsiya. Razvitie, primenenie i kontsepty ekzistentsial'nogo analiza [Fulfilled existence - development, application and concepts of existential analysis]. Kharkiv, Ukraine: Gumanitarnyi tsentr. (Original work published 2011)

Längle, A. (2019b). The history of logotherapy and existential analysis. In E. Van Deurzen, E. Craig, A. Längle, K. J. Schneider, D. Tantam, \& S. DuPlock (Eds.), The Wiley world handbook of existential therapy (pp. 309-323). Hoboken, NJ: Wiley-Blackwell.

Längle, A. (2020a). Ekzistentsial'nyi analiz [Existential analysis]. Moscow: Kogito-Centr. (Original work published 2016) 
Längle, A. (2020b). Dialogue and Dasein. How to promote the development of the psychotherapeutic process in communication and everyday life. Ekzistentsial'nyi Analiz, 12, 13-36. (in Russian)

Längle, A., Ukolova, E. M., \& Shumskiy, V. B. (2014). Sovremennyi ekzistentsial'nyi analiz: istoriya, teoriya, praktika, issledovaniya [Modern existential analysis: History, theory, practice, researches]. Moscow: Logos.

Lyotard, J.-F. (1998). Sostoyanie postmoderna [The Postmodern condition]. Saint Petersburg: Aleteiya. (Original work published 1979)

Mauss, M. (2011). Obshchestva. Obmen. Lichnost'. Trudy po sotsial'noi antropologii [Societies. Exchange. The Person. Works on social anthropology]. Moscow: KDU. (Original work published 1950)

May, R., \& Yalom, I. (2008). Existential psychotherapy. Zhurnal Prakticheskoi Psikhologii $i$ Psikhoanaliza, 4, 101-144. (in Russian)

Mounier, E. (1999). Manifest personalizma [A personalist manifesto]. Moscow: Respublika. (Original work published 1938)

Rozin, V. M. (2021). Lichnost' i ee izuchenie [The Person and its study]. Moscow: URSS.

Sartre, J.-P. (2002). Bytie i nichto. Opyt fenomenologicheskoj ontologii [Being and nothingness: An essay on phenomenological ontology]. Moscow: Respublika. (Original work published 1943)

Scheler, M. (1988). Polozhenie cheloveka v kosmose [The human place in the Cosmos]. In P. S. Gurevich (Ed.), Problema cheloveka v zapadnoi filosofii [The problem of human being in Western philosophy] (pp. 31-95). Moscow: Progress. (Original work published 1928)

Shumskii, V. B. (2020). Ekzistentsial'naya psikhologiya i psikhoterapiya [Existential psychology and psychotherapy]. Moscow: Urait.

Ukolova, E. M., \& Shumskiy, V. B. (2016). Ideya lichnosti v ekzistentsial'nom analize Viktora Frankla [The idea of the Person in the existential analysis of Viktor Frankl]. Moscow: Logos.

Vermeulen, T., \& van den Akker, R. (2010). Notes on metamodernism. Journal of Aesthetics \& Culture, 2(1), 56-77. https://doi.org/10.3402/jac.v2i0.5677

Yalom, I. (2004). Ekzistentsial'naya psikhoterapiya [Existential psychotherapy]. Moscow: Klass. (Original work published 1980) 